\title{
Cloning and partial sequencing of the proteinase gene complex from Lactococcus lactis subsp. lactis UC317
}

\author{
Jean Law, ${ }^{1,2}$ Pieter Vos, ${ }^{3} \dagger$ Finbarr Hayes, ${ }^{1,2} \ddagger$ Charles Daly,,${ }^{1,2}$ Willem M. De $\operatorname{Vos}^{3}$ and \\ GERALD FITZGERALD ${ }^{1,2 *}$ \\ ${ }^{1}$ Department of Food Microbiology, University College, Cork, Ireland \\ ${ }^{2}$ National Food Biotechnology Centre, University College, Cork, Ireland \\ ${ }^{3}$ Molecular Genetics Group, Department of Biophysical Chemistry, Netherlands Institute for Dairy Research (NIZO), \\ Ede, The Netherlands
}

(Received 18 October 1991; accepted 11 December 1991)

\begin{abstract}
The proteinase genes from Lactococcus lactis subsp. lactis UC317 were identified on a plasmid, pCI310, which is a deletion derivative of a cointegrate between pCI301, the $75 \mathrm{~kb}$ Lac Prt plasmid from UC317 and the $38.5 \mathrm{~kb}$ cryptic plasmid from that strain. The prt genes were cloned using a replacement cloning strategy whereby fragments from pCI310 were exchanged with the equivalent fragments in pNZ521, which contains the cloned proteinase genes from $L$. lactis subsp. lactis SK112. This generated two plasmids which encoded a cell-envelopeassociated and a secreted proteinase, respectively. Specific regions of the UC317 structural prtP gene known to encode seven of the amino acids essential for substrate cleavage specificity were sequenced and compared with the known sequences of prt genes from $L$. lactis strains SK112, Wg2 and NCDO763. In spite of various differences that were detected in the nucleotide sequence of this region, it appears that these seven amino acids in strains UC317 and NCDO763 are identical, and represent a combination of three of the amino acids from SK112 and four from Wg2. These results indicate that the UC317 proteinase is a natural hybrid of the SK112 and Wg2 proteinases.
\end{abstract}

\section{Introduction}

Members of the genus Lactococcus are used as starter bacteria in the manufacture of a range of fermented milk products and consequently are of considerable commercial importance (Daly, 1983; Sandine, 1988). Lactococci are nutritionally fastidious and have complex amino acid requirements (Thomas \& Pritchard, 1987). Since free amino acids are not present at sufficient levels in milk to support optimal growth of these bacteria, the concerted action of the cell-envelope-associated proteinase and a range of peptidases is required to release peptides and amino acids from the milk protein, casein. Thus in fermented milks a functional proteolytic system is essential for growth and reliable acid production, while

\footnotetext{
- Correspondence to Department of Food Microbiology, University College, Cork, Ireland. Tel. 021276871 ext. 2730; fax 021276318.

$\dagger$ Present address: Keygene, NV PO Box 216,6700 AE Wageningen, The Netherlands.

‡ Present address: Laboratory of Chromosome Biology, ABL-Basic Research Program, NCI-Frederick Cancer Research and Development Center, Frederick, MD21702, USA.

The nucleotide sequence data in this paper have been submitted to GenBank and have been assigned the accession number M85288.
}

in ripened products proteolysis is also necessary for the development of unique and fine flavour characteristics (Law \& Kolstad, 1983; Thomas \& Pritchard, 1987; Laan et al., 1989). Genetic studies have established that, like other important traits in these bacteria, proteinase production is invariably linked to plasmid DNA (Otto et al., 1982; McKay, 1985; Kok, 1990); and in several strains this trait and the lac genes have been shown to be encoded on single lactose/proteinase (Lac Prt) plasmids (McKay \& Baldwin, 1974; Gasson et al., 1987; Hayes et al., 1990).

Biochemical analysis of the cell-envelope-associated proteinases has indicated that they are serine proteinases of molecular mass approximately $145 \mathrm{kDa}$, they have a $\mathrm{pH}$ optimum between 5.5 and 6.5 and they require calcium for stable attachment to the cell envelope (Exterkate \& de Veer, 1987a; Geis et al., 1985; Hugenholtz et al., 1987; Monnet et al., 1987). Based on their casein degradation specificities, a simplified classification of proteinase enzymes from lactococci has been proposed (Visser et al., 1986). PI-type proteinases primarily degrade $\beta$-casein, with only very slow rates of hydrolysis of $\alpha$ - and $\kappa$-casein, whereas the PIII type degrade $\alpha$ - and $\kappa$-casein in addition to $\beta$-casein. 
Considerable interest has been focused on the physical characterization of proteinase genes, and those from L. lactis subsp. cremoris strains Wg2 (PI type; Kok et al., 1985, 1988), SK112 (PIII type; de Vos et al., 1989; Vos et al., 1989a,b) and L. lactis subsp. lactis NCDO763 (Kiwaki et al., 1989) have been extensively studied. In addition, parts of the proteinase genes from $L$. lactis subsp. cremoris E8 (Kok, 1990), MLl (P. Vos and others, unpublished results) and $\mathrm{H} 2$ (Xu et al., 1990), as well as that from L. lactis subsp. lactis 712 (Gasson et al., 1987), have been cloned and expressed in L. lactis or Escherichia coli. Deletion, subcloning and nucleotide sequence analyses of cloned proteinase genes from $L$. lactis subsp. cremoris $\mathrm{Wg} 2$ and SK112 have revealed the presence of two essential, adjacent but divergently transcribed genes designated prtP and prtM. The prtP gene encodes a $200 \mathrm{kDa}$ pre-pro-proteinase (Kok et al., 1988; Kiwaki et al., 1989; Vos et al., 1989a) while the prtM gene specifies a $30 \mathrm{kDa}$ lipoprotein which is implicated in the conversion of the inactive prtP product to an active form (Vos et al., 1989b; Haandrikman et al. 1989).

Preliminary studies on the purified proteinase from $L$. lactis subsp. lactis UC317 indicated that it degrades $\alpha$ and $\beta$-casein in a manner which distinguishes it from the PI-type proteinase of $\mathrm{Wg} 2$ and the PIII type of SK 112 (J. Law and others, unpublished data). These differences suggested that this enzyme possesses a novel activity, which warranted molecular analysis of the prtP gene of strain UC317. The cloning and analysis of this gene are described here. Previous results relating to the characterization of the prtP gene of $\mathrm{Wg} 2$ and SK112 allowed specific regions of the UC 317 determinant to be targeted for comparative analysis, particularly the domains responsible for substrate cleavage specificity (Vos et al., 1991).

\section{Methods}

Bacterial strains and plasmids. These are described in Table 1.

Media. E. coli strains were grown in Luria-Bertani medium (Maniatis et al., 1982) at $37^{\circ} \mathrm{C}$. Wild-type L. lactis strains were grown at $30^{\circ} \mathrm{C}$ in M17 medium (Terzaghi \& Sandine, 1975). L. lactis MG1363Sm (Gasson, 1983), the plasmid-free derivative of strain 712, was used as host in lactococcal transformations and was maintained in M17 medium in which glucose (0.5\%) replaced lactose (GM17). For solid media, agar $(1.5 \%, \mathrm{w} / \mathrm{v}$, Oxoid no. 3) was added to broth before autocla ving. Chloramphenicol ( 5 and $20 \mu \mathrm{g} \mathrm{m}^{-1}$ for L. lactis and E. coli, respectively) was included in media when required. To assess the ability of selected lactococcal strains to utilize milk proteins, reactions on fast slow differential agar (FSDA; Huggins \& Sandine, 1984) and in steamed reconstituted non-fat milk (supplemented with $0.5 \%$ glucose and/or $0.5 \%$ tryptone when required) were examined.

Chemical reagents were obtained from Sigma.

Plasmid preparation, analysis and transformation. Plasmid DNA was isolated from $E$. coli by the alkaline lysis method of Birnboim \& Doly

Table 1. Bacterial strains and plasmids

\begin{tabular}{|c|c|c|}
\hline Strain or plasmid & Characteristics & Reference or source \\
\hline $\begin{array}{l}\text { E. coli } \\
\text { MC1061 } \\
\text { TG1 }\end{array}$ & 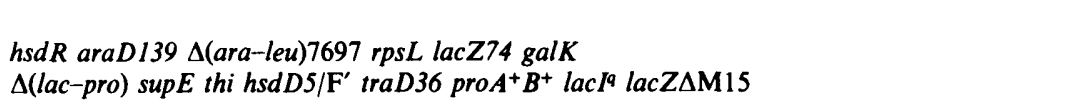 & $\begin{array}{l}\text { Casadaban \& Cohen (1980) } \\
\text { Clark (1987) }\end{array}$ \\
\hline $\begin{array}{l}\text { L. lactis } \\
\text { subsp. lactis } \\
\text { MG1363Sm } \\
\text { UC317 } \\
\text { NCDO763 } \\
\text { FH041 } \\
\text { FH048 } \\
\text { FH088 } \\
\text { J3601 } \\
\text { J3602 }\end{array}$ & 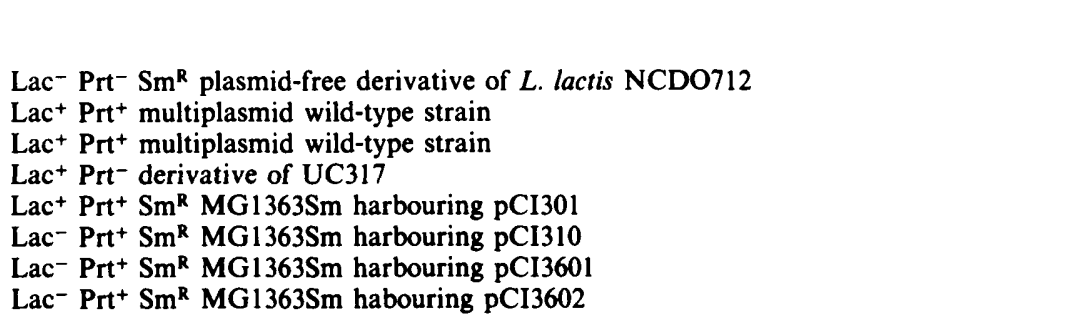 & $\begin{array}{l}\text { Gasson }(1983) \\
\text { Hayes } \text { et al. }(1990) \\
\text { NCDO culture collection } \\
\text { F. Hayes (pers. comm.) } \\
\text { F. Hayes (pers. comm.) } \\
\text { Hayes } \text { et al. }(1990) \\
\text { This work } \\
\text { This work }\end{array}$ \\
\hline $\begin{array}{l}\text { L. lactis } \\
\text { subsp. cremoris } \\
\text { SK112 } \\
\text { Wg2 }\end{array}$ & $\begin{array}{l}\mathrm{Lac}^{+} \mathrm{Prt}^{+} \text {multiplasmid wild-type strain } \\
\mathrm{Lac}^{+} \mathrm{Prt}^{+} \text {multiplasmid wild-type strain }\end{array}$ & $\begin{array}{l}\text { de Vos et al. }(1984) \\
\text { NIZO culture collection }\end{array}$ \\
\hline $\begin{array}{l}\text { Plasmids } \\
\text { pNZ122 } \\
\text { pNZ123 } \\
\text { pNZ521 } \\
\text { pCI301 } \\
\text { pCI303 } \\
\text { pCI310 } \\
\text { pCI3601 } \\
\text { pCI3602 } \\
\text { pCI3603 }\end{array}$ & 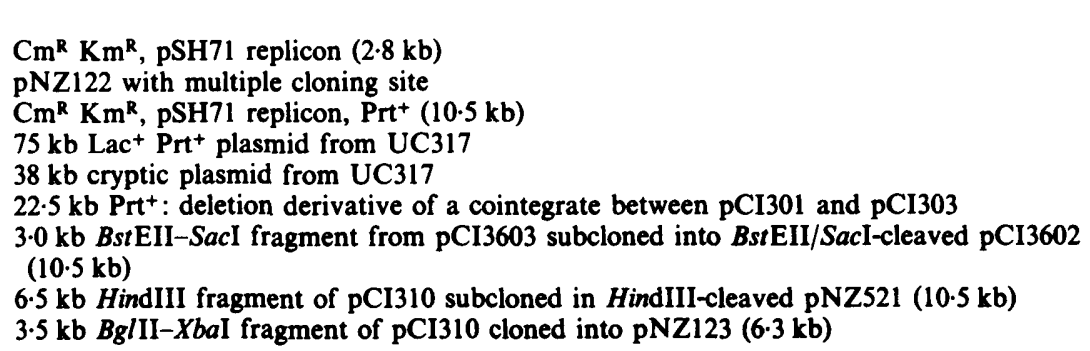 & $\begin{array}{l}\text { de Vos (1986) } \\
\text { P. Vos et al. (unpublished) } \\
\text { de Vos et al. (1989) } \\
\text { Hayes et al. }(1990) \\
\text { Hayes et al. }(1990) \\
\text { Hayes et al. }(1990) \\
\text { This work } \\
\text { This work } \\
\text { This work }\end{array}$ \\
\hline
\end{tabular}


(1979) and from $L$. lactis by a modification of this method (de Vos et al., 1984). DNA was then prepared for analysis essentially as described by Hayes et al. (1990). Restriction endonucleases and T4 DNA ligase were supplied by Pharmacia and were used according to the supplier's instructions. Restriction endonuclease digestions were analysed by electrophoresis on $0.7 \%$ horizontal agarose gels containing $0.5 \mu \mathrm{g}$ ethidium bromide $\mathrm{ml}^{-1}$ and run at $100 \mathrm{~V} \mathrm{~cm}^{-1}$ for $3 \mathrm{~h}$ in Tris/acetate (pH 7.6) buffer. DNA fragments were recovered from agarose gels using the 'Gene Clean' kit (Bio 101). E. coli was transformed by the method of Mandel \& Higa (1970); L. lactis was transformed by electroporation using a Gene Pulser apparatus (Bio-Rad), as follows. $L$. lactis MG1363Sm cells were grown in M17 medium containing $0.5 \%$ $(w / v)$ glucose and $40 \mathrm{~mm}$-DL-threonine to an $\mathrm{OD}_{600}$ of 0.5 . Cells were harvested by centrifugation, washed three times in ice-cold sterile distilled water, and resuspended in $1 / 50$ the original volume of $15 \%$ (v/v) ice-cold glycerol. DNA was added to $400 \mu$ lof cells in $2 \mathrm{~mm}$ electroporation cuvettes and subjected to an electric pulse at settings of $2.5 \mathrm{kV}, 1000 \Omega$ and $25 \mu \mathrm{F}$. Cells were immediately added to $10 \mathrm{ml}$ GM17 and incubated at $30^{\circ} \mathrm{C}$ for $90 \mathrm{~min}$, then plated on selective media.

Proteinase specificity studies. Lactococcal cells were grown on a wheybased medium containing $1.9 \%(w / v) \beta$-glycerophosphate, $0.5 \%(w / v)$ glucose and $0.1 \%(\mathrm{w} / \mathrm{v})$ casitone (Vos et al., 1989b). Cell-envelopeassociated proteinases were liberated by incubation in release buffer ( $50 \mathrm{~mm}$-sodium acetate/phosphate, $\mathrm{pH} 6.5$ ) at $30^{\circ} \mathrm{C}$ as described by Exterkate \& de Veer (1987b) while non-cell-envelope-associated proteinases were isolated by the method of Vos et al. $(1989 \mathrm{~b})$. Fractions were analysed on $0.1 \%(w / v)$ SDS, $10 \%(w / v)$ polyacrylamide gels (Laemmli, 1970) and proteins were detected by staining with Coomassie brilliant blue R-250. These fractions were also incubated with $\alpha$ - and $\beta$-casein $\left(2 \mathrm{mg} \mathrm{ml}^{-1}\right.$ dissolved in $50 \mathrm{~mm}$-sodium acetate/ phosphate buffer, pH 6.5, a generous gift from Dr S. Visser, NIZO, Ede, The Netherlands) for various time intervals and the degradation products were subsequently detected on $0.1 \%$ SDS, $20 \%$ polyacrylamide gels stained with Coomassie brilliant blue. The low-molecularmass standards ranged from $14 \cdot 3$ to $66 \mathrm{kDa}$ and were supplied by Sigma.

Nucleotide sequence analysis. All DNA fragments used for cloning into vectors M13mp10, M13mpl1, M13mp18 or M13mp19 (YanischPerron et al., 1985) were isolated from agarose gels. Replicative-form and single-stranded phage DNA was isolated from recombinant M13 clones by the method of te Riele et al. (1986). Sequencing by the dideoxynucleotide chain-termination method (Sanger et al., 1977) was performed on both single-stranded M13 DNA and double-stranded plasmid DNA and was initiated using the M1 3 universal primer or with primers synthesized on a Biosearch Cyclone DNA synthesizer (New Brunswick Scientific). All sequences were determined in both directions.

Growth rate studies. Growth rates of lactococcal cultures in milkbased medium were determined by inoculating $(2 \%, v / v)$ the test strain into $10 \%(\mathrm{w} / \mathrm{v})$ reconstituted skim milk supplemented with $0.5 \%(\mathrm{w} / \mathrm{v})$ glucose and incubating at $30^{\circ} \mathrm{C}$. The percentage of lactic acid developed was monitored at specific time intervals and the growth rates and doubling times calculated.

\section{Results}

Cloning of the prt gene complex from L. lactis subsp. lactis UC317

Plasmid pCI310 (Fig. $1 a$ ) is a $22.5 \mathrm{~kb}$ spontaneous deletion derivative of a cointegrate between the $L$. lactis (a)
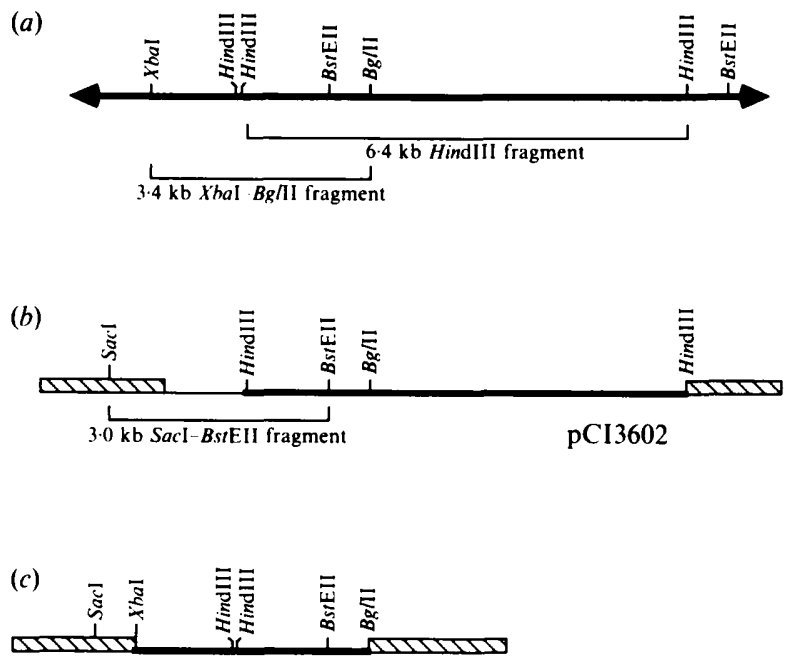

pCI3603

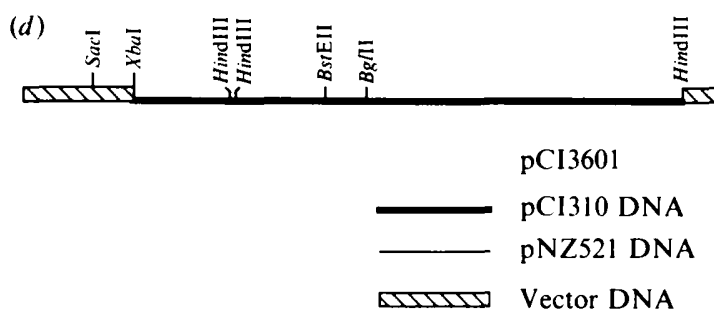

Fig. 1. Replacement strategy for cloning the L. lactis subsp. lactis UC317 proteinase genes. (a) The proteinase-encoding region of pCI310; (b) pCI3602, in which the native $6.5 \mathrm{~kb}$ HindIII fragment of pNZ521 is replaced with the equivalent fragment from pCI310; (c) pCI3603; (d) pCI3601, containing the intact proteinase genes from pCI310.

UC317 plasmids pCI301 (75 kb, Lac Prt) and pCI303 (38 kb, cryptic) (Hayes et al., 1990). Based on hybridization analysis, detailed restriction mapping and the $\mathrm{Prt}^{+}$ phenotype conferred upon pCI310-containing hosts, it has been shown that this plasmid encodes the entire proteinase complex from UC317 (Hayes et al., 1990). The prt genes of UC 317 were cloned using a replacement cloning strategy whereby a $6.5 \mathrm{~kb}$ HindIII fragment from pNZ521, which contains the cloned prtP and prt $M$ genes from SK 112, was exchanged with the equivalent $6.5 \mathrm{~kb}$ HindIII fragment from pCI310, resulting in the $10.5 \mathrm{~kb}$ plasmid pCI3602 (Fig. $1 a, b$ ).

It was found that unlike the cell-envelope-associated proteinases produced by MG1363Sm containing either pNZ521 or pCI310, the proteinase activity of the same strain harbouring $\mathrm{pCI} 3602$ could not be isolated from the cell envelope (Fig. 2, lane 1) but was found exclusively in the growth medium, indicating that the enzyme was secreted (Fig. 2, lane 2). This extracellular location can 


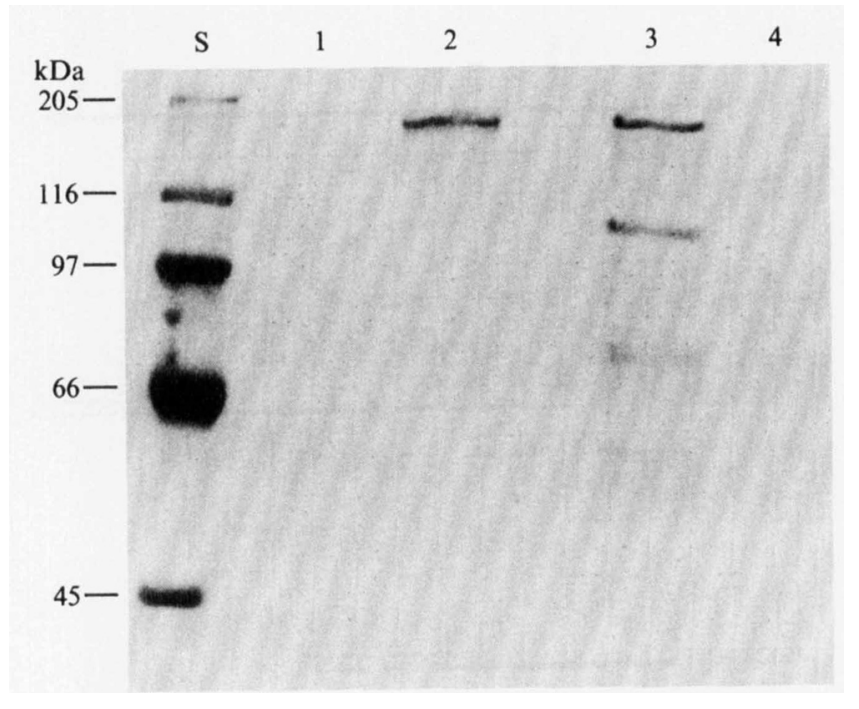

Fig. 2. Polyacrylamide gels $(10 \%, w / v)$ showing production of proteinase from MG1363Sm harbouring either pCI3601 or pCI3602. Lanes: 1, release fraction of MG1363Sm containing $\mathrm{pCI} 3602 ; 2$, growth medium fraction of MG1363Sm containing pCI3602;3, release fraction of $\mathrm{MG} 1363 \mathrm{Sm}$ containing $\mathrm{pCI} 3601 ; 4$, growth medium fraction of MG1363Sm containing $\mathrm{pCI} 3601$. S, molecular mass standards (myosin from rabbit muscle, $\beta$-galactosidase, phosphorylase $b$, bovine albumin and egg albumin) on the left.

be attributed to the deletion of a $16 \mathrm{bp}$ HindIII fragment in $\mathrm{pCI} 3602$, which results in a truncated proteinase lacking the C-terminal membrane anchor, as has been described previously (Haandrikman et al., 1989; Kiwaki et al., 1989; Vos et al., 1989a). To clone the intact and fully functional $\mathrm{C}$-terminus of the structural pCI310derived prtP gene, a $3.4 \mathrm{~kb} X b a \mathrm{I}-B g l \mathrm{II}$ fragment from pCI310 (Fig. $1 a$ ) was inserted into the high-copy-number vector pNZ123 (de Vos et al., 1989), resulting in pCI3603 (Fig. 1c). A $3.0 \mathrm{~kb} \mathrm{SacI-BstEII} \mathrm{fragment} \mathrm{from} \mathrm{pCI3603}$ was subsequently cloned into the equivalent sites on pCI3602, resulting in a $10.4 \mathrm{~kb}$ plasmid, pCI3601 (Fig. $1 d)$. As predicted, pCI3601 encoded a fully functional cell-envelope-associated proteinase in that the enzyme was located in the release fraction of the MG1363Sm host (Fig. 2, lane 3) while no enzyme was detected in the medium fraction (lane 4).

\section{Nucleotide sequence analysis of prtP from UC317}

Specific regions of the prtP gene from SK 112 which encode amino acids involved in cleavage specificity determination have been identified (Vos et al., 1991; de Vos et al., 1991). The nucleotide sequence of the equivalent regions of the UC317 structural prtP gene was determined and found to differ from that of the other known lactococcal sequences (Fig. 3). These specific
Table 2. Summary of seven of the amino acids present in the proteinases of lactococcal strains UC317, SK112, Wg2 and NCDO763 at positions important in substrate cleavage specificity

\begin{tabular}{cccc}
\hline \hline $\begin{array}{c}\text { Amino acid } \\
\text { position }\end{array}$ & UC317/NCDO763 & SK112 & Wg2 \\
\hline 131 & Thr & Ser & Thr \\
138 & Thr & Lys & Thr \\
142 & Ala & Ala & Ser \\
144 & Leu & Val & Leu \\
166 & Asp & Asn & Asp \\
747 & Arg & Arg & Leu \\
748 & Lys & Lys & Thr \\
\hline \hline
\end{tabular}

amino acids and those in corresponding positions in the proteinases of SK112, Wg2 and NCDO763 are summarized in Table 2. Analysis of the sequence shows that the UC 317 proteinase enzyme contains alanine, arginine and lysine at positions 142,747 and 748 , respectively, which are also present in the SK 112 proteinase, but absent in that of $\mathrm{Wg} 2$. However, at positions 131, 138, 144 and 166 the amino acids in the UC317 and $\mathrm{Wg} 2$ proteinases are identical, but differ from equivalently positioned amino acids in SK 112. All seven amino acids at the positions listed in Table 2 are identical in the UC317 and NCDO763 proteinases. However, when the sequence presented in Fig. 3 is examined, it is clear that the UC317 prtP gene has at least four unique nucleotides, resulting in three unique amino acids at positions 691 , 694 and 712 not present in the proteinases of NCDO763 or of the other two strains.

\section{Caseinolytic cleavage specificities}

The cleavage specificities of proteinases from $L$. lactis strains UC317, NCDO763, Wg2 and SK 112 as well as the enzymes from MG1363Sm containing either pNZ521 or pCI3601 are illustrated for $\alpha$ - and $\beta$-casein in Figs $4(a)$ and $4(b)$, respectively. The cleavage patterns on either $\alpha$ - or $\beta$-casein generated by the proteinases isolated from the wild-type UC317 host or from MG1363Sm harbouring the recombinant proteinase plasmid pCI3601 (strain J3601) were identical (Fig. 4a, $b$, lanes 2 and 3 , respectively), substantiating the previous observation by de Vos et al. (1989) that the caseinolytic cleavage specificity is determined by the prtP gene and not by the host. The cleavage patterns of the two proteinases from UC317 and NCDO763 were also identical (Fig. $4 a, b$, lanes 2 and 6). This was expected since these proteinases share the same seven amino acids involved in determining cleavage specificity (see Table 2 ). The $\mathrm{Wg} 2$-derived proteinase cleaved $\beta$-casein in an 
identical manner to UC317 and NCDO763 (Fig. $4 b$, lanes $2,6,7$ ) but did not degrade $\alpha$-casein (Fig. $4 a$, lane 7 ). The $\alpha$ - and $\beta$-caseinolytic cleavage specificities of the SK 112-derived proteinase differed from those of UC317. Although the UC317 and SK 112 enzymes yielded several cleavage products of apparently similar size from either $\alpha$ - or $\beta$-casein, the relative amounts of these products differed. For example the $20 \mathrm{kDa}$ product (Fig. $4 a$, lane 4) of the SK 112 proteinase was present in greater concentration than the equivalent-sized protein generated by the UC 317 enzyme (lane 2).

\section{Enzyme production and growth studies}

When the relative amounts of proteinase enzyme produced by UC317 and by MG1363Sm harbouring either the native Lac Prt plasmid from UC317 (strain FH048) or the cloned prt genes (strain J3601) were compared, it was clear that significantly higher levels were produced by the strains containing the cloned genes (Fig. 5, lanes 2-5). Similarly, higher levels of proteinase were produced from MG1363Sm harbouring pNZ521, which contains the cloned prt genes from SK 112, than from the wild-type SK 112 strain (Fig. 5, lanes 6 and 7), confirming the previous observations of de Vos et al. (1989). However, as expected, no proteinase production was detected in FH041, the $\mathrm{Prt}^{-}$derivative of UC317 (Fig. 5, lane 1).

The higher levels of enzyme produced by $\mathrm{J} 3601$ compared to $\mathrm{FH} 048$ also resulted in more rapid degradation of $\beta$-casein (data not shown; following 40 min incubation, complete degradation of $\beta$-casein by J3601 had occurred while significant amounts of undegraded substrate remained in the case of the FH048derived enzyme). However, it is noteworthy that no significant differences were observed between the growth rates, measured in $10 \%(w / v)$ reconstituted skim milk supplemented with $0.5 \%(\mathrm{w} / \mathrm{v})$ glucose, of FH048 $\left(\mu=0.439 \mathrm{~h}^{-1}\right)$, J3601 $\left(\mu=0.41 \mathrm{~h}^{-1}\right)$ or J3602, the isolate producing the secreted proteinase $\left(\mu=0.403 \mathrm{~h}^{-1}\right)$.

\section{Discussion}

The proteinase gene complex originally identified on the Lac Prt plasmid pCI301 of L. lactis subsp. lactis UC317 was cloned from a derivative plasmid pCI310 using a replacement cloning strategy. This approach was necessary since other more direct cloning strategies were unsuccessful. It is interesting that one of the constructs, pCI3602, encoded a secreted enzyme in contrast to the typical cell-envelope-associated enzyme generally ob- served in the lactococci (Kok, 1990), which was attributable to removal of a $16 \mathrm{bp}$ fragment during the cloning procedure used to generate this recombinant. It appears likely that the $16 \mathrm{bp}$ deletion resulted in transcription termination and consequently a truncated protein which did not possess the membrane-anchoring region (Vos et al., 1989a; Haandrikman et al., 1989).

When the proteinases were isolated from strains $\mathrm{J} 3601$ and J3602 and examined by polyacrylamide gel electrophoresis, several bands were observed in addition to the expected $145 \mathrm{kDa}$ mature proteinase (e.g. Fig. 2, lane 3). These are likely to represent autodigestion products since it has been indicated that lactococcal proteinases are subject to self-degradation at the C-terminus (Laan \& Konings, 1989).

Nucleotide sequence analysis of regions of the UC317 cloned proteinase proved fruitful in comparing its $p r t P$ gene with the well-characterized genes of SK 112, Wg2 and NCDO763. Like other lactococcal proteinases, the proteinase from UC 317 is a serine proteinase displaying a high degree of homology with the subtilisins, all of which have an active-site triad of aspartic acid, histidine and serine. Included in the regions of the UC317 proteinase which were sequenced (Fig. 3) is a histidine at position 94 which is also seen in the active sites of the SK 112, Wg2 and NCDO763 proteinases (Kok, 1990). Also within this sequence is a region including seven amino acids (Table 2) that are involved in substrate binding specificity and showing homology to the substrate-binding region of the serine proteases of the subtilisin family (Vos et al., 1991). Sequence analysis indicated differences between these amino acids in the proteinases from UC317 and from SK 112 and $\mathrm{Wg} 2$. It appears that the UC317 proteinase, like that from NCDO763, represents a new class of naturally occurring hybrid which exhibits some of the properties of both the PI- and PIII-type proteinases produced by strains $\mathrm{Wg} 2$ and SK 112 , respectively. It is tempting to speculate that a natural recombination event between genes encoding these types of activities could have been responsible for producing the UC317-type proteinase with mixed specificity. Further screening of proteinase activity in other lactococcal strains may reveal additional hybrid-type enzymes with novel caseinolytic specificities.

It is notable that enzymes with novel specificities have been engineered in vitro by interchanging regions involved in substrate cleavage specificity between the prtP genes of SK112 and Wg2 (Vos et al., 1991). Nucleotide sequence analysis revealed that the seven amino acids which determined substrate specificity are identical in UC317 and NCDO763 and, as expected, the caseinolytic cleavage specificity of UC317 and NCDO763 was also identical on $\alpha$ - and $\beta$-casein. However, despite the similarity between the UC317 and 


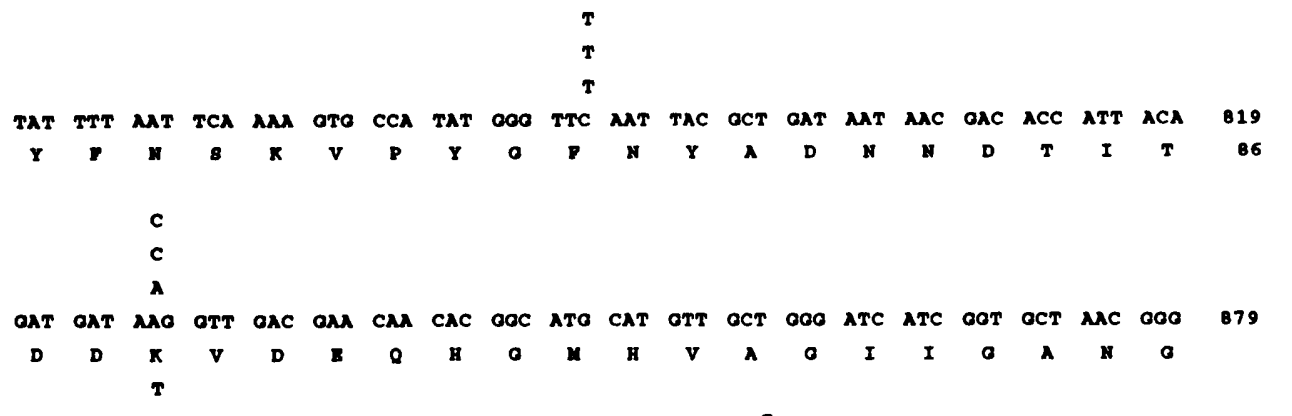

NCDO763

No 2

$8 \times 112$

UC 317

MCDO763

$\mathrm{a} 2$

$8 \times 112$

vc317

\section{a}

NCDO763

พด 2

$8 \times 112$

ACA OOT OAC OAT CCA OCC MAO TCT OTT OTC OOX OTT OCO CCA OAN OCA CAO CTA CTO OCA 939 $\begin{array}{lllllllllllllllllllllll} & 0 & D & D & P & A & X & 8 & V & V & 0 & V & A & P & E & A & 0 & \text { L } & \text { L } & \text { A } & 126\end{array}$ UC 317

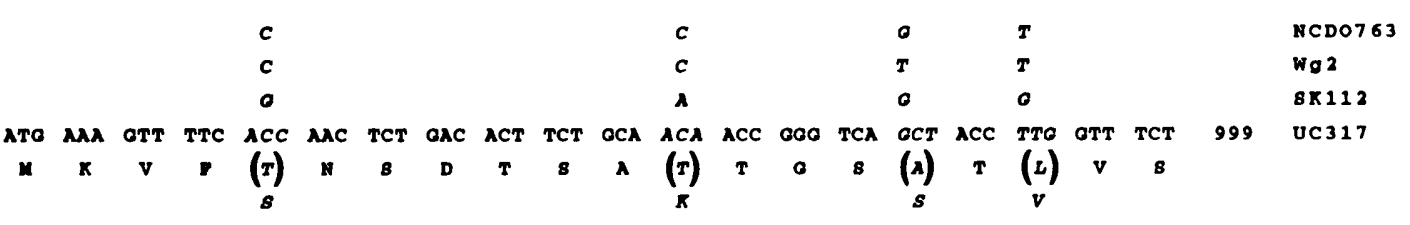

OCC ATT TAA GAC TCO GCA AAX ATC OOT GCC GAT GTC CTC AAC ATC TCC TTA OOA TCT OAT 1059 UC317

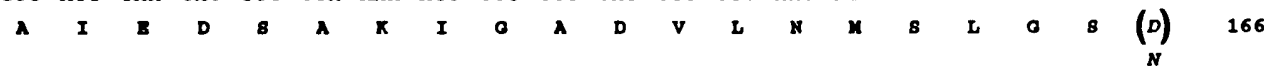

TCA OOC ANT CAN ACC TTO OAO GAT CCA OAN CTT OCT OCO OTO CAN ANT OCT AAC OAN TCA 1119 UC317

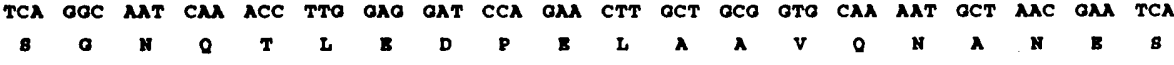

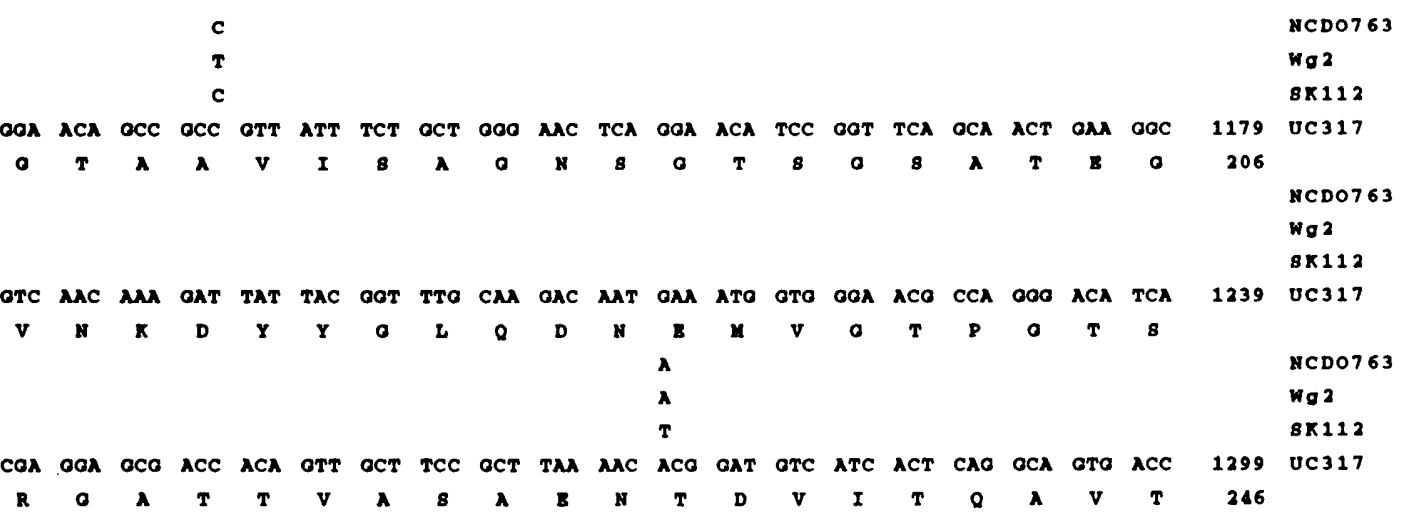

NCDO763

GOA ACA OCC OCC OTT ATT TCT OCT OOO MAC TCA GOA ACA TCC GOT TCA OCA ACT OAA OOC 1179

SCDO763

02

X112

OTC AAC MA OAT TAT TAC OOT TTO CAA OAC MAT ONA ATO OTO GOA ACO CCA OOO ACA TCA 1239 UC317

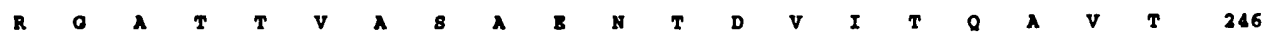

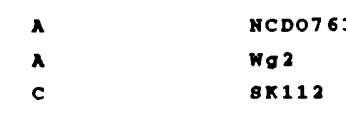

ATT ACA OAT OOT ACA OOT TTA CA, CTT OOA CCO OMA ACC ATT CAO CTT TCA AOC AAC OAT 1359 UC317
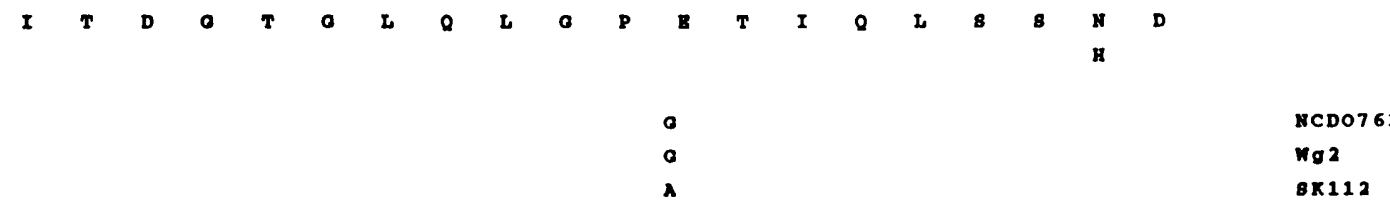

TTC ACT DOT AOC TTT OAC CMA MAO MAO TTT TAT OTT OTT MAN OAT OCT AOT GOC AAC CTC 1419 UC317 


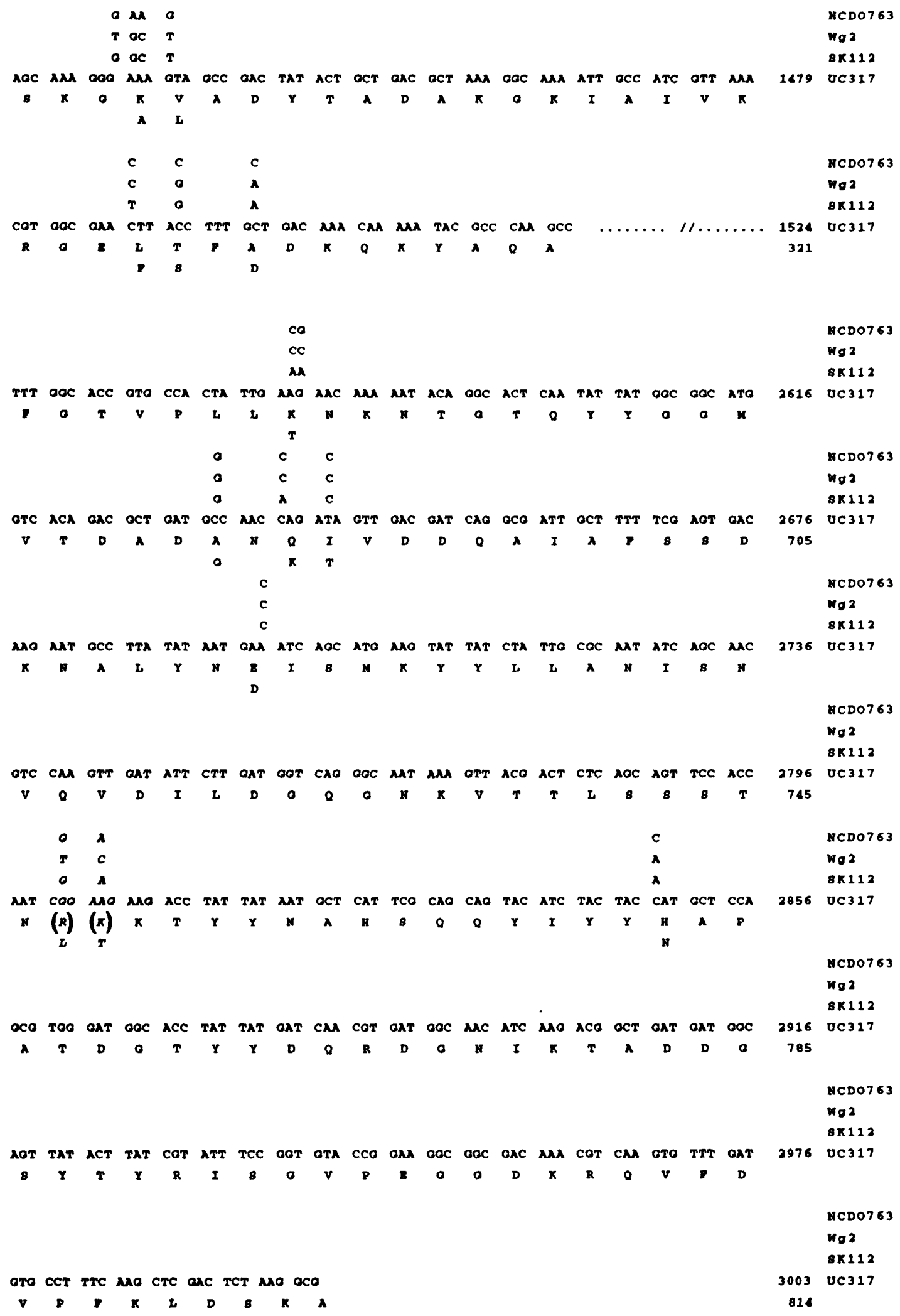

Fig. 3. Nucleotide sequence of two distinct regions of $\mathrm{pCl} 3601$ encompassing seven amino acids (each in parentheses) known to be important in substrate cleavage specificity. Nucleotide and amino acid numbers on this sequence correspond to those on the published SK112 sequence (Vos et al., 1989a), while nucleotide differences between UC317 and the SK112, Wg2 and NCDO763 sequences, respectively, are indicated in ascending order directly above this sequence. 


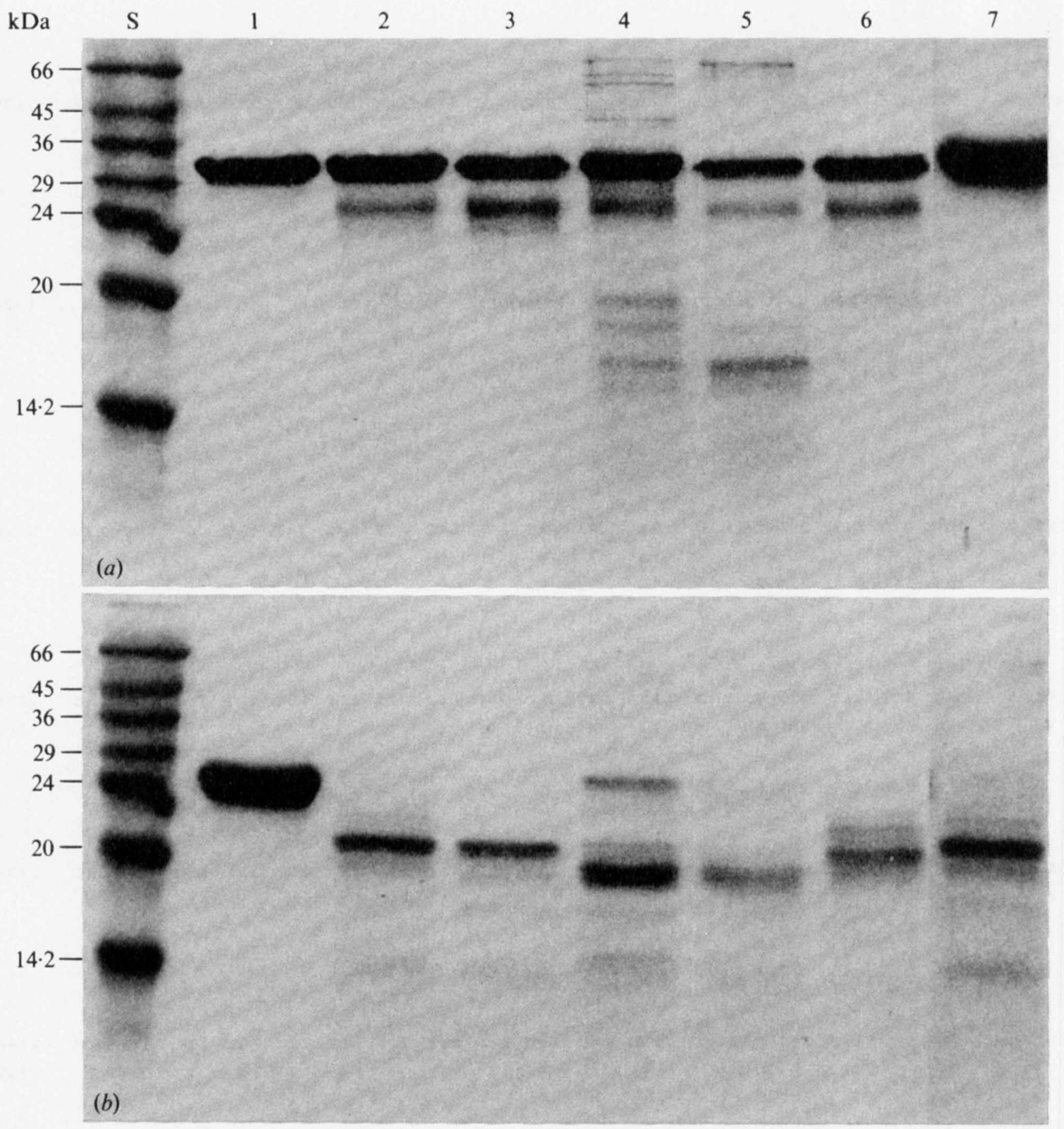

Fig. 4. Gel electrophoretograms $[0 \cdot 1 \%(w / v)$ SDS, $20 \%(w / v)$ polyacrylamide] of digestion products produced following incubation of the proteinase enzymes from UC317 (lane 2), J3601 (lane 3), SK 112 (lane 4), MG1363Sm harbouring pNZ521 (lane 5), NCDO763 (lane 6) and $\mathrm{Wg} 2$ (lane 7) with $\alpha$-casein $(a)$ or $\beta$-casein $(b)$ for $2 \mathrm{~h}$ at $30^{\circ} \mathrm{C}$. Undigested casein is shown in lanes 1 of both panels. $\mathrm{S}$, molecular mass standards (bovine albumin, egg albumin, glyceraldehyde-3-phosphate dehydrogenase, carbonic anhydrase, trypsinogen, trypsin inhibitor and $\alpha$-lactalbumin).

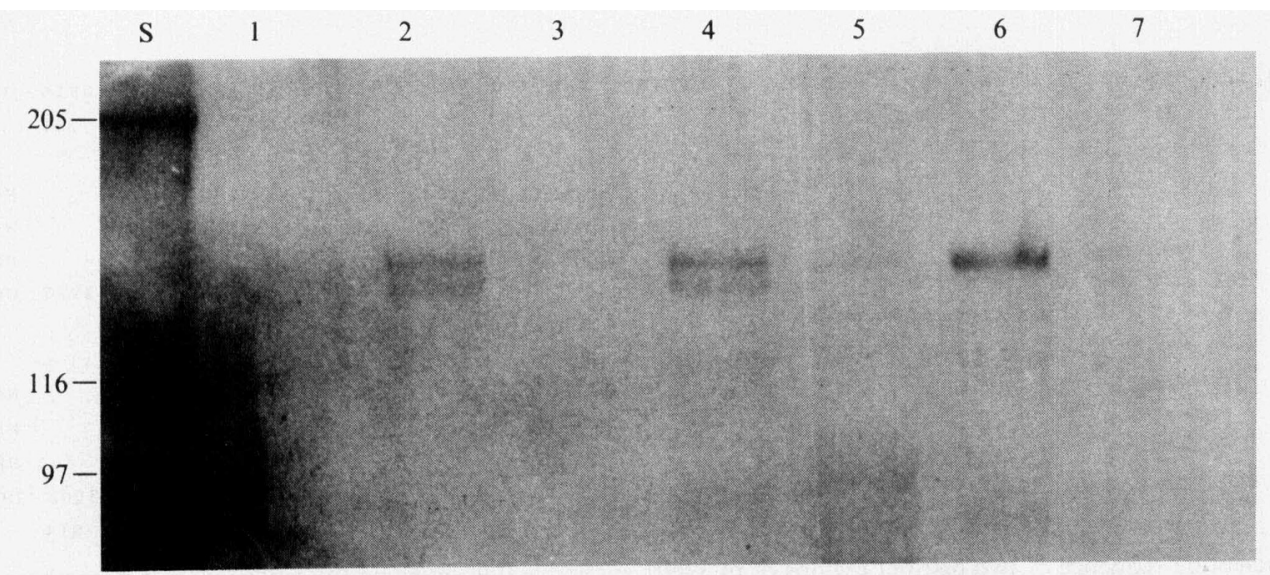

Fig. 5. Gel electrophoretograms $[0 \cdot 1 \%(w / v)$ SDS, $10 \%(w / v)$ polyacrylamide] of the proteinases isolated from the following strains: lane 1, FH041 ; lane 2, J3601; lane 3, FH048; lane 4, J3601; lane 5, UC317; lane 6, MG1363Sm(pNZ521); lane 7, SK112. S, molecular mass standards (myosin from rabbit muscle, $\beta$-galactosidase and phosphorylase $b$ ). 
NCDO763 proteins at these positions, these enzymes are not identical since UC 317 has at least three unique amino acids at positions 691,694 and 712, within the regions sequenced, not seen in $\mathrm{NCDO} 763$ or the other two sequenced proteinases. However, these differences had no effect on cleavage specificity. The cleavage patterns of the cloned proteinase enzymes in MG1363Sm were identical to those generated by the wild-type strains, indicating that specificity is independent of the host strain. These results also confirm the validity of the classification of Visser et al. (1986), who showed that PI-type proteinases degrade $\beta$ - and not $\alpha$-casein while the PIII type degrade both $\alpha$ - and $\beta$-casein. However, this and other studies indicate that it may be necessary to broaden this classification scheme to include natural hybrid enzymes with the specificities of UC317 and NCDO763 which degrade $\beta$-casein in a PI-type manner but which also degrade $\alpha$-casein like PIII-type proteinases.

Cloning of proteinase genes in a high-copy-number vector clearly resulted in higher amounts of enzyme production. This is consistent with the findings of de Vos et al. (1989). However, the greater levels of proteinase in $\mathrm{J} 3601$ and $\mathrm{J} 3602$ did not result in a higher growth rate in milk. This may indicate that the wild-type strain is able to produce the required levels of peptides for optimum growth and that their more rapid production by cloned enzymes would therefore have no stimulatory effect.

This work was supported by the European Communities Biotechnology Action Programme (Contract BAP-0008-IRL.) and BioResearch Ireland. Jean Law wishes to extend sincere gratitude to Professor W. M. de Vos, Dr P. Vos and all her friends in the Molecular Genetics Group for welcoming her at the NIZO and making her stay there so enjoyable.

\section{References}

Birnboim, H. C. \& Doly, J. (1979). Rapid alkaline extraction procedure for screening recombinant plasmid DNA. Nucleic Acids Research 7, 1513-1523.

Casadaban, M. J. \& Cohen, S. N. (1980). Analysis of gene control signals by DNA fusion and cloning in Escherichia coli. Journal of Molecular Biology 143, 179-207.

Clark, P. (1987). Improved oligonucleotide-directed mutagenesis using M13 vectors. Methods in Enzymology 154, 382-402.

Daly, C. (1983). The use of mesophilic starter cultures in the dairy industry. Antonie van Leeuwenhoek 49, 297-312.

Exterkate, F. A. \& DE VeER, G. J. C. M. (1987a). Partial isolation and degradation of caseins by cell wall proteinase(s) of Streptococcus cremoris HP. Applied and Environmental Microbiology 49, 328-332.

Exterkate, F. A. \& De Veer, G. J. C. M. (1987b). Complexity of the native cell wall proteinase of Lactococcus lactis subsp. cremoris HP and purification of the enzyme. Systematic and Applied Microbiology 9, 183-191.

Gasson, M. J. (1983). Plasmid complements of Streptococcus lactis NCDO 712 and other lactic streptococci after protoplast induced curing. Journal of Bacteriology 154, 1-9.
Gasson, M. J., Hill, S. A. \& Anderson, P. H. (1987). Molecular genetics of metabolic traits in lactococci. In Streptococcal Genetics, pp. 241-245. Edited by J. J. Ferretti \& R. Curtiss III. Washington, DC: American Society for Microbiology.

Geis, A., Bockelman, W. \& Teuber, M. (1985). Simultaneous extraction and purification of a cell wall associated peptidase and a $\beta$-casein specific proteinase from Streptococcus cremoris AC1. Applied Microbiology and Biotechnology 23, 79-84.

Haandrikman, A. J., Kox, J., Laan, H., Soemitro, S., Ledeboer, A. M., Konings, W. N. \& Venema, G. (1989). Identification of a gene required for maturation of an extracellular lactococcal serine proteinase. Journal of Bacteriology 171, 2789-2794.

hayes, F., Caplice, E., McSweeney, A., Fitzgerald, G. F. \& Daly, C. (1990). pAMBl-associated mobilisation of proteinase plasmids from Lactococcus lactis subsp. lactis UC317 and L. lactis subsp. cremoris UC205. Applied and Environmental Microbiology 56, 202-209.

Hugenholtz, J., van Sinderen, D., KoK, J. \& Konings, W. N. (1987). The cell wall associated proteases of Streptococcus cremoris Wg2. Applied and Environmental Microbiology 53, 853-859.

HugGins, A. R. \& SANDINE, W. E. (1984). Differentiation of fast and slow acid producing strains of lactic streptococci. Journal of Dairy Science 67, 1674-1679.

Kiwaki, M., Ikemura, H., Shimizu-Kadota, M. \& Hirashima, a. (1989). Molecular characterisation of a cell wall associated proteinase gene from Streptococcus lactis NCDO763. Molecular Microbiology 3, 359-369.

KoK, J. (1990). Genetics of the proteolytic system of lactic acid bacteria. FEMS Microbiology Reviews 87, 15-42.

KoK, J., van Dijl, J. M., van der Vossen, J. M. B. M. \& Venema, G. (1985). Cloning and expression of a Streptococcus cremoris proteinase in Bacillus subtilis and Streptococcus lactis. Applied and Environmental Microbiology 50, 94-101.

KoK, J., Leenhouts, K. J., HaAndrikman, A. J., Ledeboer, A. M. \& VENEMA, G. (1988). Nucleotide sequence of the cell wall proteinase gene of Streptococcus cremoris $\mathrm{Wg} 2$. Applied and Environmental Microbiology 54, 231-238.

LAAN, H. \& KonINGS, W. N. (1989). Mechanism of proteinase release from Lactococcus lactis subsp. cremoris $\mathrm{Wg} 2$. Applied and Environmental Microbiology 55, 3101-3106.

LAaN, H., Smid, E. J., TAN, P. S. T. \& Konings, W. N. (1989). Enzymes involved in the degradation and utilisation of casein in Lactococcus lactis. Netherlands Milk and Dairy Journal 43, 327-345.

LAEMMLI, U. K. (1970). Characterisation of structural proteins during assembly of the head of bacteriophage T4. Nature, London 227, 680-685.

Law, B. A. \& Kolstad, J. (1983). Proteolytic systems in lactic acid bacteria. Antonie van Leeuwenhoek 49, 297-312.

Mandel, M. \& HigA, A. (1970). Calcium dependent bacteriophage DNA infection. Journal of Molecular Biology 53, 159-162.

Maniatis, T. E., Fritsch, E. F. \& Sambroox, J. (1982). Molecular Cloning: a Laboratory Manual. Cold Spring Harbor, NY: Cold Spring Harbor Laboratory.

MCKAY, L. L. (1985). Roles of plasmids in starter cultures. In Bacterial Starter Cultures for Foods, pp. 159-174. Edited by S. E. Gilliland. Boca Raton, Florida: CRC Press.

MCKAY, L. L. \& BALDWIN, K. A. (1974). Simultaneous loss of proteinase and lactose utilising activities in Streptococcus lactis and reversal of loss by transduction. Applied Microbiology 28, 342346.

Monnet, V., Le Bars, D. \& Gripon, J. C. (1987). Purification and characterisation of a cell wall proteinase from Streptococcus lactis NCDO763. Journal of Dairy Reserach 54, 247-255.

OTto, R., DE Vos, W. M. \& GaVRieli, J. (1982). Plasmid DNA in Streptococcus cremoris $\mathrm{Wg} 2$ : influence of $\mathrm{pH}$ on selection in chemostats of a variant lacking a protease plasmid. Applied and Environmental Microbiology 43, 1272-1277.

TE Riele, H., MICHEL, B. \& EHRLICH, S. D. (1986). Are single stranded circles intermediates in plasmid DNA replication? EMBO Journal 5 , 631-637.

SANDINE, W. E. (1988). New nomenclature of the non-rod shaped lactic acid bacteria. Biochimie 70, 519-522. 
SANGer, F., Nicklen S. \& Coulson, A. R. (1977). DNA sequencing with chain-terminating inhibitors. Proceedings of the National Academy of Sciences of the United States of America 82, 1074-1078.

TERZAGHI, B. E. \& SANDINE, W. E. (1975). Improved media for lactic streptococci and their bacteriophages. Applied Microbiology 29, 807-813.

Thomas, T. D. \& Pritchard, G. G. (1987). Proteolytic enzymes of dairy starter cultures. FEMS Microbiology Reviews 46, 245-268.

Visser, S., Exterkate, F. A., Slangen, C. J. \& de Veer, G. J. C. M. (1986). Comparative study of action of cell wall proteinases from various strains of Streptococcus cremoris on bovine $\alpha \mathrm{s} 1-, \beta$ - and $\kappa$-casein. Applied and Environmental Microbiology 52, 1162-1166.

Vos, P., Siezen, R. J., Simons, G. \& de Vos, W. M. (1989a). Primary structure and organisation of the gene for a procaryotic cell envelopelocated serine proteinase. Journal of Biological Chemistry 264, 13579-13586.

Vos, P., van Asseldonk, M., van Jeveren, F., Siezen, R., Simons, G. \& DE Vos, W. M. (1989b). A maturation protein is essential for production of active forms of Lactococcus lactis SK11 serine proteinase located in or secreted from the cell envelope. Journal of Bacteriology 171, 2795-2802.

Vos, P., Boerrigter, I. J., Buist, G., HaAndrikman, A. J., Nijhuis, M., De Reuver, M. B., Siezen, R. J., Venema, G., DE Vos, W. M. \& KoK, J. (1991). Engineering of the Lactococcus lactis serine proteinase by construction of hybrid enzymes. Protein Engineering 4 , 479-484.
DE Vos, W. M. (1986). Genetic improvement of starter streptococci by the cloning and expression of the gene encoding a non-bitter proteinase. In Biomolecular Engineering in the European Community, pp. 465-471. Edited by E. Magnien. Dordrecht: Martinus Nijhoff. DE Vos, W. M., Underwood, H. \& Davies, F. L. (1984). Plasmid encoded bacteriophage resistance in Streptococcus cremoris SK 11. FEMS Microbiology Letters 23, 175-178.

De Vos, W. M., Vos, P., de HaARd, H. \& Boerrigter, I. (1989). Cloning and expression of the Lactococcus lactis subsp. cremoris SK 11 gene encoding an extracellular serine proteinase. Gene 85, 169-176.

De Vos, W. M., Boerrigter, I., Vos, P., Bruinenberg, P. \& Siezen, R. J. (1991). Production, processing and engineering of the Lactococcus lactis SK 11 proteinase. In Genetics and Molecular Biology of Streptococci, Lactococci and Enterococci, pp. 115-119. Edited by G. Dunny, P. Cleary \& L. McKay. Washington, DC: American Society for Microbiology.

Xu, F. F., Pearce, L. E. \& Yu, P. L. (1990). Molecular cloning and expression of a proteinase gene from Lactococcus lactis subsp. cremoris $\mathrm{H} 2$ and construction of a new lactococcal vector pFX1. Archives of Microbiology 154, 99-104.

Yanisch-Perron, C., Vieira, J. \& Messing, J. (1985). Improved M13 phage cloning vectors and host strains: nucleotide sequence of the M13 mpl8 and pUC19 vectors. Gene 33, 103-119. 